\title{
Social Construction of Social Work Identity in The Processes of its Institutionalisation
}

\author{
P Navrátil ${ }^{1 *}$ and P Bajer ${ }^{2}$ \\ Masaryk University, Brno, The Czech Republic, Europe
}

Submission: May 17, 2018; Published: August 20, 2018

"Corresponding author: P Navrátil, Masaryk University, Brno, The Czech Republic, Europe; Email:17824@mail.muni.cz

\begin{abstract}
The aim of the text is to explain the process of social construction of social work identity / identities, which (the process of social construction) I introduce as an important part in social work institutionalisation. Some social workers think that their work within the frame of their profession has a permanent and unchangeable character. The conception of the permanent and unchangeable character of social work excludes the theory, values and methodology use from possible discussion and reflexive verification. The orientation towards only one model of values, theory and methods runs the risk of harming clients and in a wider sense risks destabilizing social relations.
\end{abstract}

Keywords: Social Construction; Social Work; Social problems; Institutionalisation; Professional project

\section{Introduction}

Social work came into being as a professional project. The term "professional project" follows from the Weberian understanding of society as an environment in which subjects compete for their economic, political and social recognition. We suppose that this effort to establish a social work profession with regard to its professional and status aspects was in western world accomplished. It gave rise to a consolidated theoretical basis; professional associations exist, which control the quality of their community members; ethical codices were established, academic magazines are published and scientific conferences take place [1].

However, several authors notice that the current understanding of social work in the Euro-American area is unclear and full of contradictions [2]. There are voices talking even about social work crisis; there are a number of explanations of the characteristics of this crisis. According to many authors, the crises includes various phenomena, such as professional identity loss, professional borders erosion, lacking profession acknowledgement by society, insufficient numbers of qualified social workers, increase in the numbers of paraprofessionals, high fluctuation level of social workers, social work performance by non-qualified workers, lacking economic resources, social state reduction, etc.

In the Czech Republic, the forming of social work was complicated by the fact, that the process of social work institutionalisation was interrupted several times during the 20 th century. In the era of the First Czechoslovak Republic, social work began to advance promisingly, but this development was soon disturbed by the occupation of Czech lands by fascist armed forces during World War II. In the post-war years, communist ideology had negative influence on its development by denying the existence of social problems, which practically prevented the development of a profession that was to resolve them. In the context of these impacts, social work in the Czech Republic developed differently than in countries with democratic regimes. In fact, professional identity was not established here during the 20 th century at all. Social work was performed in a few areas only, one of which (the most significant) is represented by the area of child and youth protection. The modern shaping of social work in the post-communist era has been taking place for more than twenty years. During this formation period, social work went through a dynamic search for its professional identity, which is currently anchored in the definitions of its goals, values and conceptions, in its legislation and institutional organisation, and also in well-proven activities of social work professionals. Despite of this, some Czech authors point out that social work as a profession has not been established or only partly [3].

We opine that it is purposeful to explore this multi-faceted phenomenon by means of the term of "unclear professional identity". There are a number of reflections about what may be the reason for the unclear identity of social work. One of these theses states that the reason for the unclear identity is a large spectrum of activities that fall within the authority of social workers. It is very probable, however, that the professional identity crisis is related to a number of factors, which extend beyond one sole dimension. Therefore, we suppose that social work identity is created in multidimensional processes of social 
construction, which both create and recreate the social work identity within communication processes. Most important (not exclusive, however) bearers of this communication about social work are also social workers and social work recipients (clients, users of social services). Although it is indisputable that other important actors (profession-oriented educational institutions, politicians, employers of social workers, ect.) play a role in the social construction and identity of the profession, the former bearers shall be the ones, whose perceptions and social work constructions would be interesting to make the key subject of empirical research.

The text proceeds from the social constructivism theory [4]. Its fundamental presumption states that reality is an intersection of objective facts and subjective interpretations. In the context of social constructivism institutionalisation happens through knowledge sharing in social processes, which organise the knowledge and make it objective. By repeating them, social activities become reality and people start considering them as given. Human behaviour is influenced by conventions based on shared knowledge. These conventions become institutionalised, as soon as a certain amount of people agrees with a way of understanding a specific aspect of society. Then, such a way of understanding is legitimised in a process, during which it receives certain meanings, which integrate such conception within an organised and acceptable system. Such conception of reality becomes objective, because it is widely shared. One of institutions created in this way is also formalised help to people (social work).

It seems indisputable that social and cultural factors condition both the contents and forms of social work [5]. Despite of this, some authors state that certain elements form its part always and everywhere [6]. Payne considers social workers, clients and context as such elements. Although this list may be regarded as sufficient, I opine that is would be more adequate to extend it by another general structural element - social problem. Its social definition is a prerequisite for the realisation of social work activities. Social work as a profession and a specific activity was established as a reaction to the need to resolve certain social problems. Therefore, I surmise that social problem belongs to the fundamental elements that define the structure of social work. Hence, in our text, it is important to follow, how social construction of social work is performed on the level of these four elements.

Everyday experience shows that cohabitation of people in a society is burdened by various conflicts and problems, from which some only gain the significance and a status of a social problem. Neither science, nor any other institution has a generally accepted list of criteria, based on which it would be possible to determine, what a social problem is and what not. Both political decisions and research works are often influenced by society's attitudes in this matter. As has been stated above, there is no unified, scientific-research approach to this question. Sociologists define social problem according to the concept chosen by them as their explanation scheme $[7,8]$. From the viewpoint of social work, the theory chosen plays a significant role in the processes of social situation assessment. This text proceeds primarily from the value conflict theory and labelling theory, as interpreted by Herbert Blumer [9]. Blumer [9: 102] writes: "social problems are a result of a process of collective definition". His concept enables to capture the social-constructivist aspect of social problem definition. A number of other authors also support the opinion that social problems are primarily constituted in the collective social-constructional process [10].

The role of a social worker is constructed by professional expectations, by which we understand a set of presumptions that specify his / her tasks and social processes, in which they become social workers [11]. Professional expectations are influenced by the history of social work, its relations with other professions and social institutions. Professional expectations can vary about socio-cultural conditions, and they cannot be considered as indisputably given; often, they are perceived by social workers as threatening [12] and dilemmatic $[13,14]$. There are several roles, which social workers can play. The role of social worker includes the role of defender, counsellor, case worker, partner, risk assessor, care manager and social control agent. This list is without doubt not exhaustive. It rather hints at the conflict potential of these roles.

It is practically impossible to identify all factors that take part in the changes of the social construction of social worker's role. Even several social processes and institutions that have no direct connection to the academic or practical level of social work play a significant role in forming its character. As an example, let us name legislation changes, interests of other professions, etc. Perception of social needs by politicians and the public influences the society's reaction to these needs. Political debate, media presentation of social worker's role has an impact on its perception, and, in connection with this, on the tasks and focus of social workers $[15,16]$. Social worker's goals will be defined in one way in an organisation, where social work is a dominant profession, in a different way there, where another profession dominates (health care institutions, youth detention centres). The relationships between the state, the employers and employees may play a significant role, too. In the countries, where employee conditions are negotiated with the participation of trade unions (or other professional associations), these bodies influence the character of work [17].

Some of the social groups and institutions mentioned above stand in conflict - potentially or actually. The academic development of social work can be prevented by the interests of other professions. There may be a conflict between the employer's social work tasks definition, political requirements and a professional definition. The above-named actors and possibly other interest groups influence public meaning, organisational structures, the political system and legislation, in order to strengthen their control both over the theory and definition of social worker's performance and role [18]. The 
matter of unclear definition of social worker's role has even a stronger impact on the new areas of international social work [19].

Whether someone is considered a client or not, is a matter of perception Parton and O'Byrne (2000b). If people consider somebody a client, they can treat him accordingly. His / her own status definition has a certain influence, however not decisive. Formally labelling a person as a client is also significant. It can be the source of such perception or of its reinforcement. Such perception can be shared by the client, social workers, people from other organisations, the client's family members, etc. The client status may persist, although social work for a client was interrupted or terminated. The client status can be linked with a certain category of people. For example, it can be connected with a specific social class, a territory, etc. The client status may be related to a stigma. To be a client is not a state, but rather a dynamic process. People become clients, act in the client role and also abandon it [6].

Social work is performed in the context of an organisation e.g. within a group of people, which was established to achieve certain goals. An organisation is a set of social relationships that influence the social construction of social work. Organisations stand under by economic, political, organisational and academic pressure, which also influences both social workers and clients. The currently most important factor having a significant impact on social work identity is the welfare state revision.

\section{References}

1. Payne M (2006) What is Professional Social Work? Policy Press, London, UK.

2. McDonald C (2006) Challenging Social Work: the context of practice. Palgrave Macmillan New York, USA.

3. Chytil O (2007) Epilogue: Walter Lorenz - Social Work - Central and Eastern European Countries. Social Work \& Society 5(3).
4. Berger LP, Luckmann T (1996) The social construction of reality. Doubleday New York, USA.

5. Navrátil P, Musil L (2000) Sociální práce s příslušníky menšinových skupin. Sociální exkluze a nové tř́dy (5): 127-163.

6. Payne M (2005) Modern Social Work Theory 3 edtn. Palgrave Macmillan Basingstoke, England, UK.

7. Qureshi H (2004) Evidence in Policy and Practice: What Kinds of Research Designs? Journal of Social Work 4(1): 7-23.

8. Frič P (1989) Sociológia sociálnych problémov v USA. Sociológia 21: 633-647.

9. Blumer H (1975) Soziale Probleme als kollektives Verhalten. In: Menschliche Bedurfnisse und Soziale Steuerung, Hondrich KV (Eds.) Quelle und Hayer, Hamburg, Germany, pp. 102-113.

10. D'cruz H (2004) The Social Construction of Child Maltreatment: The Role of Medical Practitioners. Journal of Social Work 4(1): 99-123.

11. Havrdová Z and L Zamykalová (2001)Profesní struktura a kvalifikační předpoklady pracovníků v sociálních službách. 1 edtn Praha: VÚPSV.

12. Ševčíková, S. and P. Navrátil (2010) Sociální práce jako institucionalizace rizika v pozdně moderní době. Sociální studia 7(2):19.

13. Musil L (2004) „ráda bych Vám pomohla, ale“: dilemata práce s klienty v organizacích. (1 $1^{\text {st }}$ edn), Marek Zeman, Brno.

14. Nečasová M, Profesní etika (2003) In Metody a řízení v sociální práci. Portál: Praha 21-49.

15. Lorenz W (2000) The European Perspectives in Social Work. In: Blackwell Encyclopaedia of Social Work, Davies M (Eds.), Oxford, Blackwell, United Kingdom.

16. Munday B (2003) European social services: A map of characteristics and trends Strasbourg: Council of Europe.

17. Birkenmaier J, D Mc Gartland Rubio, M Berg Weger (2002) Human Service Nonprofit Agencies: Studying the Impact of Policy Changes. Journal of Social Work 2(2): 133-147.

18. Wilensky HL, Lebeaux CN (1965) Society and social welfare: The impact of industrialization on the supply and organization of social welfare services in the United States. The Free Press: New York, USA.

19. Midgley J (2001) Issues in International Social Work: Resolving Critical Debates in the Profession. Journal of Social Work 1(1): 21-35.

\begin{tabular}{|l|}
\hline \multicolumn{1}{|c|}{ Your next submission with Juniper Publishers } \\
will reach you the below assets \\
- Quality Editorial service \\
- Swift Peer Review \\
- Reprints availability \\
- E-prints Service \\
- Manuscript Podcast for convenient understanding \\
- Global attainment for your research \\
- Manuscript accessibility in different formats \\
( Pdf, E-pub, Full Text, Audio) \\
- Unceasing customer service \\
Track the below URL for one-step submission \\
https://juniperpublishers.com/online-submission.php \\
\hline
\end{tabular}

